\title{
The Impact of housing reform on consumption, investment, and industrial growth: a tale of three Chinese cities
}

Peng Du and Sun Sheng Han

National University of Singapore

Paper prepared for the Seventh Annual Conference, Pacific Rim Real Estate Society, 21-24 January 2001, Adelaide, Australia

\begin{abstract}
Housing reform has been a key component in China's economic revitalization program initiated by the late paramount leader Deng Xiaoping since 1978. By reforming the welfare housing system, the Chinese government aims at the removal of a burden (i.e., welfare housing) from state finance. At the same time, housing reform will stimulate changes in consumption, investment, and related industrial sectors, and thus facilitate economic growth. This paper examines the impact of housing reform on consumption, investment, and industrial growth in three Chinese cities. Data are collected from field reconnaissance, government policy documents and census materials, covering the period 1985-1998. Descriptive statistics and correlation analysis are used for analyzing the data. Research findings revealed that housing reform resulted in drastic changes in housing investment and growth of related industries. Self-raised capital became the main source of housing investment, while state investment declined considerably. Significant correlations were clearly discernible between housing investment and related industries. Nevertheless, the power of resident's consumption, as measured by the percentage expenditure on real property, household articles and services, was a constraint against housing commercialization. Further reforms to raise the level of effective demand for housing, and to introduce various schemes in housing finance are critical for developing the housing industry into an engine of economic growth.
\end{abstract}

Keywords : Housing Reform; Economic Growth; Cities; China 


\section{The impact of housing reform on consumption, investment, and industrial growth: a tale of three Chinese cities}

\section{Introduction}

Before the economic revitalization program initiated by the late paramount leader Deng Xiaoping in 1978, China had operated within a centrally planned economic system. Housing consumption was considered as social welfare and all public-sector housing was distributed free of charge among public-sector employees. Housing investment was regarded as "non-productive investment" and was kept at a limited scale. Such system had brought about many serious problems such as housing shortage, insufficient investment, unfair distribution, low rent and poor management (Wang and Murie, 1995). The China's housing system under the planned economy was first attacked by the wave of reform in 1979. The purpose of housing reform is to end the so-called welfare provision of housing so as to reduce the burden on the state as well as the individual work units (Li, 2000).

The reform program has changed the general public's perception of the state housing provision and introduced many new elements in housing provision such as high rent, home ownership, compulsory housing savings and commercial housing development and distribution. The highly-concentrated planning system for housing investment has been broken, and multiple channels of housing investment have been set up with the participation of enterprises and individuals and the growing up of housing development companies. The low rent system has been shaken and changed in many cities. Miniature housing markets connecting suppliers and consumers have emerged. The single form of public ownership of housing has been improved with the 
increase of private investment and promotion of individual homeownership. All these changes have contributed to the great improvement of housing conditions of the urban residents.

The housing policies and practice in China have attracted attention from government officials and researchers both in and outside China. The literature on China's housing system and reform has expanded considerably in recent years. Most of the published work tends to present general descriptions of China's old and new housing policy, or study housing issues as part of urban planning (for example, Ma and Hanten, 1981; Badcock, 1986; Kwok, 1988; Kim, 1987; Lee, 1988; Lin, 1989; Fabre, 1990; Lim and Lee, 1990; Kirkby, 1990; Dowall, 1994). Some report political ideology and housing inequalities (for example Lim, Zhou and Logan, 1996); Some study housing finance (for example Okpala, 1994); Some explore housing commercialization (for example Liu, 1989; Chiu, 1995; Gu and Colwell, 1996; Wang and Murie, 1996). There are also some case studies (for example Wang, 1992, 1995; Chiu, 1996a) carried out in major Chinese cities. These studies have made important contributions to the analysis and understanding of China's housing system.

It is worth noticing that with the stable and rapid economic growth after the economic reform, China's economic structure is also changing and adjusting at a fast speed. However, there is little study on the impact of housing sector, especially after housing reform measures are introduced on national economy. According to the international experience, when a nation has entered the long-term sustained economic growth, the residents expenditure on housing will be increasing, which will lead to a growing share of housing investment in the national total investment. Housing, as a 
main part of construction industry, will become one of the pillar industries in the national economy. Three research questions are raised in this study. First, What changes has China's housing reforms brought about in the structure of households' consumption? Second, What impact has China's housing reform had on housing investment system? Finally, Is housing reform relevant to the growth of related industrial sectors?

The purpose of this article is to examine the variations of the three different channels by which housing sector could contribute towards economic growth in the Chinese context. In particular, this study attempts to exam the variation of these three channels during the housing reform and to identify which seems most effective to economic growth. Recent housing reform going on in China's cities provides ideal cases for such research: A market oriented housing allot system was introduced which treat housing as a commodity that can be sold or purchased by urban residents instead of a welfare provided by the government. Housing funds comes not only from individual income but also from HPFs (Housing Provident Funds) and mortgage loans. Housing investment now comes through multiple channels which not only includes capital from state budget, but also includes domestic loans, foreign capital, state treasury bond and self-raised capital etc. This means that the burden of accommodating urban residents should be shared among individuals, enterprises and government (Office of Leading Group of Housing Reform Under State Council 1991). Moreover, the construction system and technological level of housing industry in a sense depends on the development of several related industries such as building material industry, civil engineering industry, decoration industry and so on. The reform of housing policy and sharp increase of housing construction in China's cities 
is fascinating to evaluate the impact of housing reform on consumption, investment and industries growth. It is expected that after the housing reform, the housing related consumption should become a major part in the household's total consumer spending; housing investment should mainly come form self-raised channel and there should be a close relationship between housing investment and related industries.

\section{Literature review}

Many studies have been conducted to test the housing (real estate) market, economic growth and the relationship between them. For example, Ermisch (1990) reviewed the interaction of the housing market and housing policy with the operation of the national economy. By examining the British housing market development, the end of mortgage rationing, the house price movement with effects on consumption and saving and supply side issue, he argued that the absence of a rental market affects the nature of house price movement which further affects consumption and saving decisions, the risk faced by household, and labor mobility.

Recent analysis by Dipasquale and Wheaton (1996) illustrates the important differences between demand-induced growth and supply-induced growth by using the simple three-sector model of metropolitan economic growth. Their discussion shows that an increase in the demand for a region's products increases regional output, employment, and stock of real estate, as well as output prices, wages, and real estate rents. Output, employment, and stock rise more than output prices, wages, and rents when factors are readily available and elastically supplied. On the other hand, an increase in the supply of labor (an outward shift in the supply curve) increases output, employment, the stock of real estate, and real estate rents, but wages and output prices 
fall. The increase in quantities and rent is large relative to the decreases in wages and output prices when output demand is price elastic.

Study on the relationship between China's housing market and economic growth is very rare, however, there are few works in this field in the West. Hollander and Nathan (1963) discussed the general relationship between housing and economic development. He point out that the process of providing better housing is a manysided exercise in economic development, the achievement of better housing, in turn, has profound effects on social organization and political attitudes which are carriers of economic development. Well-aimed housing programs within the means of the middle class can help to attach them to existing social order and make them breeder of enterprise, management, and technical and professional skills.

Housing also affects economic development directly in four aspects: first of all, housing is a form of investment competing with other forms for a limited supply of investment funds. Secondly, housing offers a unique opportunity to mobilize private savings that would otherwise be immobilized or unavailable for productive uses. Thirdly, in many countries where money market are nonexistent and savings institutions are rudimentary, housing offers an opportunity for motivation and channeling of saving which otherwise be lacking. Finally, housing is one of the early forms of industrial development and a stimulus to a variety of auxiliary industries and trades (Hollander and Nathan, 1963).

A more recent work was done by Woodfield (1989). According to Woodfield, the strategy consideration in renewing growth that technological advances and the slow growth of the industrialized countries have reduced their demand for many developing countries' primary products in 1980s, thus, growth strategies oriented towards the export sector are not likely by themselves alone to supply sufficient stimulus to reactivate growth. Housing is one of the principal sectors that can catalyze domestic growth without generating more inflation, with negligible demands on foreign exchange and with little recourse to the fiscal exchequer. 
Studies on China's housing reform in terms of consumption and investment hardly link housing and economic growth together. For example, Lim and Lee (1993) examined the effect of social, political, and economic factors on consumption of housing in China. By using time-series and cross-section analysis, they found that rent reform alone cannot successfully improve the Chinese housing situation. Li (2000) conducted a comparative study of housing consumption in Beijing and Guangzhou, drawing upon two surveys of newly completed commodity housing conducted in 1996. The results show that the level of housing consumption varies systematically with the type of housing and the degree of market penetration of individual city. In both cities, the work unit still constitutes the single most important buyer and distributor of commodity housing. In other words, the traditional redistributive system still exerts tremendous influence on the housing consumption.

Although Hollander and Nathan (1963) pointed out that the housing could promote the economic development through related industrial sectors, to the best of our knowledge, however, there lacks detailed study in this aspect. There are some articles mentioned about the housing related industrial sectors in Chinese periodicals. For example, Mei (1999) predicted that every 100 yuan of housing fund would lead to 170-220 yuan of demand from related industrial sectors, every sale of 100 yuan of housing would cause the sale of $130-150$ yuan of related products. But the basis of his claim remains unknown.

The review of the housing reform and economic growth theory provides the following main points. First, there are some theoretical evidence on the close relationship between housing reform and economic growth. Second, the growth model 
suggests that the economic growth occurs as a result of either the shift in the demand for regional products or the shift in the supply of resource. Third, past studies on the housing reform tend to focus on the consumption (demand) side, little is known about the changes on supply side. Moreover, another important area of study which test the relationship between the housing and its related industrial sectors has almost been untouched.

\section{Data and framework}

Because of the uneven social and economic conditions of different regions in China, different reform programs-privatization, rent increases and so on-are not implemented simultaneously in every city and the specific reform schemes vary significantly from city to city. For example, privatization is more common in southern cities and small cities and towns than in large and more centrally controlled cities. Generalized discussion, therefore, might not be able to probe intensively into the question under consideration. Thus, a case study approach is adopted in this paper. The research is based on case studies of three Chinese cities- Yantai, Shenzhen, and Shanghai. There are two reasons to choose these three cities as samples: First, the investigation of a single case does not allow for a valid generalization from sample to population characteristics. Second, each city has distinct characteristics in housing reform measures, which can be seen as representatives of cities with similar social and economic context. Yantai belongs to the group of cities that were selected to join the early housing reform experiment carried out in the 1980s and it established China's first bank dedicated to housing finance. Shenzhen is a representative of coastal cities that benefit from flexible open policy as well as foreign investment. The Shenzhen's scheme of raising the rents with wage subsidize was recently promoted by the Ministry of Construction as one of the most feasible approaches in subsidized rent reform. Shanghai is selected based on its strong mercantile traditions as well as benefiting from central government policies over the last two decades. Moreover, it is one of the pioneers in formulating and establishing the housing provident funds system in China. 
The research data are collected from field reconnaissance, government policy documents and census materials, covering the period 1985-1998 (for some cities, where latest data are available, policies measures in 1999 or 2000 are also discussed). Major statistical procedures employed in this study include descriptive statistics and correlation analysis.

The diagram below represents the framework of this study:

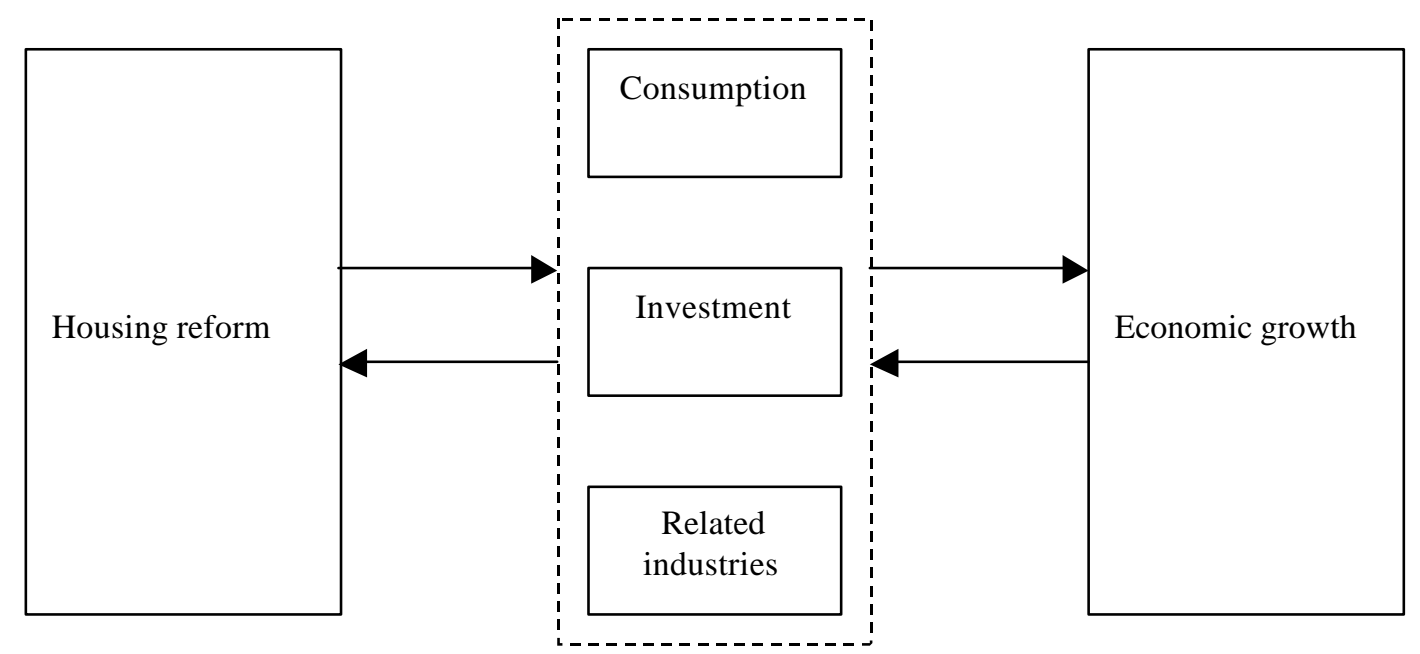

The improvement of people's housing standard and the achievement of housing can be regarded as an index of the national economy. First, housing industry enjoys an immense market demands as the urban residences are still in great shortage. The potential of household consumption on housing is remarkable and thus plays an important part in the market-orientated economies. Second, the Chinese housing investment in recent years takes $7.5 \%$ of the GNP. It forms gigantic momentum in deposition and can furnish enormous impacts on economic growth through financial depth, inflation rate, and labor resources flow and payment balance. Third, housing is highly interrelated industrial sectors. Thus, the sound development of housing industry would promote the development of national economy through several related industrial sectors. 
On the other hand, the performance of economic growth also has a great impact on housing industry. The economic developed regions tend to attract more human talent and rural people than less developed regions. With the number of people going to cities and towns continue to increase, the demand on housing is also likely to rise. When taking the whole housing industry into consideration, its construction funds, building scale, and technology level directly depends on the household consumption, source of investment and several related industrial sectors. The housing industry would thus be stimulated through these three channels.

Table 1 summarizes the main characteristics of the sample cities. It shows that among the three sample cities, Shenzhen enjoys the highest value in both GDP per capita and GDP growth rate. Shanghai has the largest population scale and density in urban areas. It also attracts the largest amount of foreign investment. Yantai has the highest living standard. Compared with Shenzhen and Shanghai, its primary industry takes the largest share in GDP.

Table 2 shows the main reform events during housing reform. It reveals some distinct features of the three sample cities: Yantai started housing reform plan earlier than other two cities but it lacks further measures to deepening the reform; Shenzhen carried out its reform plan stage by stage with new reform measures adopted each year accord with the national housing reform strategy; Shanghai started is a pioneer in establishing HPFs in China and use it as a breakthrough point in its housing reform.

\section{Yantai}


Yantai locates at the eastern tip of Shandong province, borders Yellow Sea on the south and Bohai Sea on the north. The total area is $13,506 \mathrm{sq} \mathrm{km}$, including the city and 8 counties, with 6.44 million population in 1999. The urban area accounted for 2,643 sq km with 1.95 million population.

Yantai has established a sound industrial base in light industries, foodstuffs, textiles, electronics, machinery, chemicals, building materials, silk, instruments, chemicals, metallurgical production and coal industries. There are more than 2,430 enterprises with over 2,600 different types of industrial products, of which more than 600 products are exported. The 4 main traditional industries in Yantai are wines, canned food, wooden-frame clocks and pad-locks. Upcoming industries include automobiles, powered machinery, freezers, computers, flannelette, spandex and leather products.

Yantai was also known as one of the early pioneers in implementing housing reform. In 1987 Yantai was selected by the State Council to experiment with reforms in commercialization of housing production, distribution, and consumption. The objectives of the Yantai reform plan were gradually to commercialize the entire process of housing production, distribution and consumption. The major method was to increase rent in the public sector to the level which could cover the standard cost, at the same time and for the first time to issue special housing-subsidy coupons which have equal value to Chinese currency but could only be used for housing consumption. This measure was to compensate the loss caused by the increase of rent under the low-salary system. Housing subsidy was to be gradually phased out and salaries would increase to a sufficient level to meet family housing cost. The long- 
term goal of the plan was to establish a housing market in which the state and other employers would have no direct distribution function in housing. The new rent covered five elements: depreciation charge ( 2 per cent discount per year), repair and maintenance costs (an average of 2.1 yuan/sq m/year), investment interest (an annual rate of 3 per cent), management costs and property tax. After a complicated calculation, an average standard monthly rent of 1.17 yuan per square meter in the city's central built-up area was proposed. At the same time 23.5 per cent of the tenants total salary would be issued in the form of housing coupons.

The subsidy level was based on the principle that the total rent increase in the city should equal the total housing subsidy so that the reform would not incur extra costs to the government. The reform was designed neither to increase household's housing costs nor to increase state housing investment. It aimed to change the process of housing production and distribution. Through the reform, housing distribution would be changed from material distribution to monetary distribution. It was anticipated that after the reform, people would only acquire housing of a size which they could afford. People occupying bigger houses in the old system would pay more rent. During the transition period, families suffering too heavy a loss because of this reform were to be compensated up to a certain limit. Eventually, these families would be encouraged to change their house for a small, affordable one. For families whose new rent was less than the subsidy, the surplus coupons would go to a special housing fund managed by bank. The saving could only be used by the family for purchasing a house in the future. By doing this, the direct housing link between employers and their employees would be broken. Housing provision would become a service which could be 
effectively dealt with by specialized housing authorities and other social organizations.

Along with rent changes, the Yantai housing reform plan encouraged publicsector workers to buy the houses they occupied. Standard sale prices were proposed. Tenants were required to pay a minimum 30 per cent of the price at the outset; the remaining part was to be paid through installments over a period of 10-15 years. Special discounts were proposed to encourage higher initial payments. At the same time, a new housing finance system was introduced to ensure that the incomes generated from rents and sales were used for house building. The policy-makers also anticipated major changes in the tenure pattern in the city with a mixture of private, institutional/enterprise and city government ownership in each housing estate or even within a single building. The plan proposed to establish independent neighborhood housing service companies to manage repairs, public facilities and other services in each area. The costs of the services would be each area. The costs of the services would be shared by the property owners, whether they were public or private. The implementation of these proposals was reported to be very successful. It changed some of the traditional ideas in housing distribution. Many people with no previous intention of buying a house have been considering buying. About 3000 households living in larger state houses in the city decided to exchange for smaller apartments in line with their affordability. In addition, around 1500 households gave up the houses which were allocated to them, but which they had not been occupying. Because of the rent increases, housing authorities had more money for maintenance and management (Tang and Xie, 1992, pp.1131). The Yantai plan was the most comprehensive 
approach yet adopted and received a lot of attention. Most of its elements were later incorporated into central government policies.

Figure 1 shows the historical change of major items of consumption spending in terms of percentage to total consumption spending in Yantai from 1985 to 1998. It appears that during the period 1985-1998 food consumption took the largest portion in households' consumption spending, while clothing and recreation spending came up as the second and third largest parts. The spending on housing and other services and residence did not change much until 1991 and 1992, after that the percentage of consumption on these two items rose steadily and took the fourth and fifth place respectively after 1997 . This sudden rise was mainly caused by the rent reform, which had been tested in selected districts since 1988. It was gradually implemented in the entire city urban area since then. However, the low rent did not give enough incentive to households to purchase their housing, the process of commercialization has therefore been very slow As a result, the average scale of housing consumption was quite low especially compared with food consumption.

With the growth of real estate industry in China after 1978, some financial intermediaries started to provide short-term construction loans to developers of commercial housing. Since 1982, more financial institutions got involved in business of deposits for housing. Two local specialized housing banks were established in Yantai and Bengbu respectively in December 1985 and May 1988. In 1985, Yantai's mayor, Yu Zhengsheng, established China's first bank dedicated to housing finance. With Yantai Housing Saving Bank (YHSB) as an example, the major source of funds was from enterprises, which represented 84 percent of the bank's total deposits base. 
And the enterprises deposits were mainly from: their retained profits, working capitals, sale incomes of existing housing stock, loans for fixed assets construction and development funds for renovation of old housing. The compulsory saving from individuals comprised 16 percent of its total source of funds, of which 95 percent were contracted saving with YHSB for home purchase.

In 1989, 70 percent of the bank funds were used or lent to workunits and real estate companies as current capitals. Loans to workunits for the purchase and construction of home amounted to 2.4 percent in the use of funds, while the volume of mortgage loans to individual households constituted only 1.9 percent of the bank's total loan portfolio. This showed that most of its lending were directed to workunits and real estate companies while individuals as the final consumer of housing were left out or neglected. More worse than the restrict services, the interest rates for both deposits and loans were set lower than other prevailing rates. The interest paid on deposits was lower than those of temporary deposits and interest spread between saving and lending was set at 1.8 percent. Under these regulations, its operation were characterized with strict administrative control and remain small due to its limited range of services and its self-closed flow of housing funds with no access to large resources of funds in the whole financial market.

Yantai's experiment in privatization did not provide a feasible model for the country as a whole. The cost of housing construction proved to be far beyond the means of the average urban household. In order for low-income urban residents to be able to afford a housing unit, local governments and enterprises had to pay large subsidies. A World Bank study of housing reform in China even recommended 
against privatization, citing the low rates of private housing in Germany and the United States, with 40 percent and 65 percent respectively (World Bank, 1992).

Figure 2 shows that the percentage of self-raised capital had been higher than other sources of investment. The self-raised capital increased from $42 \%$ in 1985 to nearly $45 \%$ in 1998, which is the lowest among all sample cities. The percentage of capital from the state budget had experienced drastic fluctuations. It increased from $27 \%$ in 1985 to $31 \%$ in 1986 and dropped suddenly to $5 \%$ in 1987 , then it rose quickly to its highest point at $41 \%$ in 1989 , after that, it decreased steadily until reaching $2 \%$ in 1998 . The high percentage of investment from the state budget and the relatively low percentage of self-raised investment shows the failure of reform measures in Yantai to some extent. The underlying causes are many: one is the high down-payment (IFTE, 1996). Under the prudent underwriting criteria, the loan-tovalue ratio are 50 percent, which includes 30 percent down-payment and a deposit with the lending bank equivalent to 20 percent of the total cost of home purchase; second is the short maturities of loans. After a series of complicated procedures and satisfying all the requirements of the bank, the longest repayment term for individual borrowers is around 10-15 years. In effect, such high down-payment and short maturities, added by 20 percent "preferential discount" to home buyers with lumpsum payments, only encourage cash settlement, which limits the opportunities for operation and expansion of mortgage lending. In conclusion, although mortgage finance, as a common instrument, has been adopted by most of countries in housing finance, it failed to play the same role in China as it does in other market-oriented economies. 
The 1990s witnessed the rapid development of Yantai's construction industry. The total output value of construction industry raised from 21.88 million yuan in 1993 to 50.69 million yuan in 1996. It dropped slightly to 47.32 million yuan in 1997 before increased to 52.98 million yuan in 1999. The construction industry has absorbed a large number of labors as well, thus playing an important role in stabilizing rural areas and increasing urban employment. Statistics shows that there were 11.64 million employees working in the construction industry in 1993, the number increased to 16.67 million in 1996, and maintained at 12.68 million in 1999.

The development of housing reform and growth of construction industry has spurred on the development of several industrial sectors. Among the twelve selected industrial sectors, the electric equipment and machinery industry and the civil engineering have achieved a faster growth rate (Table 3). The output value of electric equipment and machinery industry increased gradually from 306.33 million yuan in 1985 to 660.78 in 1990 . In the 1998 , the same output value reached 5889.29 million yuan, which was 19 times that of 1985 . The output value of the civil engineering industry did not have a consistent record before 1994. Statistics from 1994 to 1998 shows that the output value of civil engineering industry increased from 1031.16 million yuan to 3110.31 million yuan. Most of the increase was achieved from 1995 to 1996 and the growth rate was $150 \%$ during this period. Other related industrial sectors had increased slowly or fluctuated depending on government policy changes and their capacity for production.

Table 6 shows the Pearson correlation coefficients for those variables that yield significant relationships with the housing development indicator. Among the twelve 
variables that represent housing related industries, six show significant direct relationship with housing investment in Yantai. These six variables are: (a) furniture manufacturing; (b) electricity, steam and hot water production and supply; (c) gas production and supply; (d) tap water production and supply; (e) cement; (f) steel. The coefficients of the above seven variables are supportive of a statement that there is a close and direct relationship between housing investment and development of related industries.

\section{Shenzhen}

Shenzhen was designated as one of the four SEZs (Special Economic Zones) in 1979. Preferential policies and liberalization of central government control have brought tremendous growth to Shenzhen since then. From 1979 to 1999, the total population of Shenzhen increased 12.9 times from 314,100 to 4,051,300. Today, Shenzhen is a medium sized city popular for visitors to and from Hong Kong, and also a manufacturing center producing electronics, pharmaceuticals, chemicals, textiles, building materials, and processed foods. Shenzhen residents enjoy a higher level of wage and standard of living than the average of the Chinese.

At its start, Shenzhen adopted the same welfare housing system as all other cities in China. The state borne the responsibility of providing housing for the residents. From 1979 to 1987 state investment in housing amounted to 22.4 billion yuan, counting for $23 \%$ of the total investment in fixed assets and $20.36 \%$ of the gross national income. A total housing space of 5.96 million square meters were constructed during this period. Nevertheless, housing supply failed to meet the ever-increasing 
housing demand. At the end of 1987, there were 22,000 households in short of housing (Shenzhen Jing ji Te Qu Nian Jian 1989 pp.176), which was more than three times than that in 1983 (i.e., 5000 households). Though the fast growth of population was attributable to the housing shortage to a certain extent, a more important reason was the rigid and highly centralized housing system.

The municipal government set up a task force in charge of housing reform in March 1987. A year later, in June 1988, the Housing Reform Plan of Shenzhen Special Economic Zone (HRPSZSEZ hereafter) was promulgated. This plan was officially put into practice in October 1988. The objectives of housing reform in Shenzhen, as spelt in the above plan, were to lighten the heavy fiscal burden from the state (i.e., in the forms of government organizations and state-owned enterprises) in housing construction; to boost up the consumption of housing; to accelerate circulation of funds in the real estate market; and eventually to achieve a market equilibrium of housing supply and demand.

One major change in Shenzhen's reform approach was to increase housing rent. According to the HRPSZSEZ, housing rental could cost as high as $25 \%$ of the basic salary of employees. As a start, monthly rental was benchmarked at 2.06 yuan per sq $m$ per month in 1988. The above rent was calculated by including five elements: depreciation charge (an average of 0.42 yuan per sq $\mathrm{m}$ per month) and investment interest (an average of 1.19 yuan per sq m per month), building cost (an average of 0.15 yuan per sq m per month), repair, maintenance and management cost (an average of 0.05 yuan per sq m per month) and property tax (an average of 0.25 yuan per sq $\mathrm{m}$ per month). Adjustment was done every two years by introducing additional 
increments. In 2000, Shenzhen's housing rental reached 6.54 yuan per sq m per month. This rental level is significantly higher than that in other Chinese cities. For example, the monthly rent in Shanghai was 1.92 yuan per sq $m$ in 2000. In Guangzhou it was 2.52 yuan per sq $\mathrm{m}$. In Chengdu it was 2.90 yuan per sq $\mathrm{m}$.

By June 1989, housing reform was carried out in all party and government offices and administrative units. The total money collected from sale of public housing was 3.15 billion yuan, total rent collected from housing rent was 0.25 million yuan.

The increase of housing rent, together with sales of housing which is discussed in the next paragraph, led to the increase of residents' spending on housing and related items (Figure 3). From 1990 to 1998, it appears that food consumption took the largest portion in households' spending, but it dropped gradually from $47 \%$ in 1990 to $32 \%$ in 1998. The spending on housing and other services and residence decreased except in 1994 and 1998, after that the percentage of consumption on these two items rose steadily and took the third and fifth place respectively after 1997. This sudden rise was mainly caused by the rent reform, which had been tested in selected units or districts since 1998. Although the average scale of housing consumption was still low compared with food consumption, they were relatively high compared with other sample cities. This is especially true for the high percentage of consumption on residence, which shows the significant result of rent reform in Shenzhen.

The other major change was to encourage residents to purchase their own housing. This was done by providing housing units with reasonable price on the one hand, and by providing necessary housing finance on the other. In the HRPSZSEZ, it was 
envisioned that housing would be priced differently to go through three stages. Housing price would not include land price nor development profits in the first stage, so that the lowest possible price would be offered to residents. As residents' purchasing power would increase along with further reform, housing price would increase to include land price but still excluded the development profits. In stage three, development profits would be charged to consumers so that a free market equivalent housing price would be in operation.

Thus, the existing housing stock was split into old (i.e., those occupied before the promulgation of the Plan in 1988) and new (i.e., those were constructed after 1988). The cost of the old housing was calculated based on the "Chong Zhi Jian Zhao Chen Ban" of 1987 (HRPSZSEZ), while the cost of new housing was calculated according to quasi-cost which includes building cost, project management cost and interest during the construction.

The municipal government of Shenzhen has set up a so-called "Double-track and Three categories" housing supply system since 1989. According to the system, housing would be constructed either by housing bureau of the government or real estate companies. All constructed housing could be classified into three categories: Anju housing which covered basic cost, Anju housing with little profit and commercial housing. The government took charge of the construction of the first two housing types. The former Anju housing was provided to employees in party and government offices and administrative unites, while the later was provided to employees from enterprises that were short of housing or need financial assistant from the government. The third type is provided to the employees that can afford market 
housing price. The three kinds of housing also different from each other in terms of land use policy, price, and property right management.

Through Anju projects, the housing investment has achieved a benign circulation: sale the housing that already constructed, then use the funds to construct new housing and sale again. The government was thus able to establish the Governmental Housing Funds collected form sale of old public housing. During the 11 years of housing reform, Shenzhen has constructed more than ten Anju residential quarters, which were mainly supported by the governmental housing funds. In 1998, the constructed area covered 1485,000 square meters with a total investment of 13 billion, at the same time the Governmental Housing Funds raised from 1.35 billion at the beginning of the reform to 8 billion by the end of 1998 .

Figure 4 plots the percentage of different investment channels in the total housing investment in Shenzhen from 1990 to 1998. A clear pattern in terms of housing investment by ownership structure is evident during this period, namely, the most rapidly growth channel was from self-raised capital, which increased from $39 \%$ in 1990 to nearly $90 \%$ in 1998 , whereas the capital from the state budget and state treasury bond remained at a nominal level. Proportion from other channels, such as domestic loans and foreign capital, had fluctuated depending on government housing policy changes and their capacity for housing investment. It shows that housing construction in Shenzhen had been mainly dependent on self-raised capital and foreign investment, while support from the state was almost neglectable. 
The increase of housing rent and sale of housing went hand in hand with a housing allowance. In addition, Shenzhen introduced the "Housing Provident Funds" (HPFs) in 1992. Employees and workunits each contributed $13 \%$ of wages in Shenzhen. The HPFs was put together with age and medical insurance. The funds were managed by Shenzhen Social Security Bureau and could only be used to housing related investment. Although employees could not apply for housing mortgage loans from HPFs management institution, the system gave a certain support to individual housing privatization.

From 1988 to 1999 , around 400,000 residents became owner of their housing. The total Anju housing sold added up to 155,500 units.

Shenzhen's construction industry has been growing rapidly after the economic reform and open policy were introduced. The total output value of construction industry raised from 17.04 million yuan in 1979 to 10962.08 million yuan in 1997. Except for the period from 1985 to 1987 , the total output value had been increasing steadily. The average growth rate during the 1990 to 1992 was as high as $71 \%$.

The development of housing reform and growth of construction industry has spurred on the development of several industrial sectors. Among the nine selected industrial sectors, the electric equipment and machinery industry and the electricity, steam and hot water production and supply have achieved the fastest growth rate (Table 4). The output value of electric equipment and machinery industry increased gradually from 885.06 million yuan in 1990 to 9228.51 million yuan in 1998, which was 10 times that of 1990. Statistics shows that the output value of the electricity, 
steam and hot water production and supply increased from 184.47 million yuan in 1990 to 11870.98 million yuan in 1998. Most of the increase was achieved from 1996 to 1997 and the growth rate was $710 \%$ during this period. Other related industrial sectors had increased slowly or fluctuated during this period of time.

The Pearson correlation coefficients show that among the nine variables that represent housing related industries, four show significant direct relationship with housing investment in Yantai (Table 6). These four variables are: (a) furniture manufacturing; (b) electric equipment and machinery; (c) electricity, steam and hot water production and supply; (d) tap water production and supply. The coefficients of the above four variables are supportive of a statement that there is a close and direct relationship between housing investment and development of related industries.

\section{Shanghai}

Shanghai covers an area of $6,340.5$ square kilometers, with a population of 14.74 million in 1990. Housing shortage has long been a severe problem in Shanghai, partly due to the historical legacy of large population base and poor housing conditions inherited from the past, and partly because of the regional development polices that undermined Shanghai's economic growth. Indeed, Shanghai was a 'cash cow' to the central government with limited investment back to its non-productive sectors, such as housing, until the 1980s (Han 2000). As such, Shanghai's per capital living space registered a historical low point of 4.3 square meters in 1979. 
During the period 1990 to 1993 , the total floor space of houses for sale or rent reached 4.2 million square meters and accounted for 20.4 percent of the total floor space of all residences in Shanghai. Meanwhile, the local government was undertaking two important reforms. The first was the implementation of large-scale privatization of housing. Older state-owned residential units, with independent kitchens and toilets, are being sold to individuals at preferential prices. The government hopes that these reforms to the housing system will speed up urban house construction, allowing the target of 10 square meters of per capita living space to be achieved by the end of the century. The second was the establishment of the Housing Provident Funds. According to the Shanghai Municipal Construction Commission, the establishment of a Housing Provident Funds (HPFs) was introduced in 1991 and all other cities subsequently adopted. The basic theories of the PAF system are:

a. Housing should be supported by employees and their work units together. The fund is managed by HPFs management center and can only be used in housing related expenditures. Contributions to the fund vary from one year to another. In 1991, for example, employees and workunits each contributed 5\% of wages in Shanghai. Such rate is adopted by many other cities in their own schemes. By the end of 1999, the number of employees participating in the Public Accumulation Fund system had reached 69 million in China, and some 140.9 billion yuan had been collected for the fund, representing an increase of 39.8 billion yuan over the previous year.

b. The HPFs helps speed up the circulation of housing funds. The housing funds are first accumulated through HPFs system. Housing constructions will then be financed by mortgage loans from HPFs management center. After the construction, 
households can buy their houses at cost price, thus their expenditure will cover the construction cost and circulate back to HPFs management center.

c. The individuals' consumption pattern will be changed by the compulsory HPFs system. It is estimated that if both employees and their work units contribute $10 \%$ of constant wages, the total amount of HPFs accumulated in 40 years will equal to their 4 years salary, which could help employees to buy a house with no less than 40 sq. $\mathrm{m}$. living space per capita at cost price.

Although the HPFs system will definitely contribute to the increase of household expenditure on housing and improve their consumption pattern in the long run, its operation mechanism also has some negative effects which needs more study. First, the operation of the funds has adopted "low deposits and, lending interest rates". In other words, the interests paid on deposits are relatively low and interests on loans are charged a little bit higher than deposits interest rate. Such funds arrangement would lead to cut its flow of funds from the main stream of the whole banking system and financial market. Second, a part of the compulsory saving has been used for high return projects which would hurt the benefits and the interests of the broad savers. Finally, since the HPFs was adopted as a new alternative to housing finance, the government should take some measures to abolish the old housing financial system in order to ease the burden of workunits. But things seem just the opposite: for a longtime workunits were still the main bodies in housing financing and construction.

In the Shanghai scheme, there are two approaches to reforming the old rent system. First, the rent is raised to such a level that tenant payment can cover routine 
maintenance and management expenditure, and this means that payments have raised from an average 0.27 to 0.45 yuan per square meter monthly. The ultimate goal is to gradually upward readjust the rent, from the present $3-5$ percent of a household's total income, to almost 15 percent by the year 2000. Second, all newly allocated rental housing will be subject to the household purchase of a five-year bond carrying a nominal interest payment. These bonds are calculated on a per square meter of rented space basis and vary according to housing quality (seven grades) and location (five grades). For example, 65 yuan per square meter of newly allocated housing of the highest quality in downtown Shanghai, 50 yuan per square meter in suburban areas, and 35 yuan at Shanghai's periphery. Although the approach of a five-year housing bond has been an improvement over existing practices, it has had a limited impact.

A World Bank report commented 'since the housing bonds are redeemable within five years, their impact on household rental expenditures is limited, when compared to the policy of redemption only on vacating the premises' (World Bank 1992:31). Such effects can be seen from Figure 5, which shows the percentage of consumption in household facilities and services had decreased in Shanghai from 1985-1998 with few exceptions in 1988,1989 and during the period from 1992 to 1995 . On the other hand, the consumption on residence increased gradually during the same time period.

The change of consumption structure in Shanghai might be able to illustrate two things. First, It shows that The National Housing Reform Plan 1988 and The Urban Housing Reform Resolution 1991 were effective in raising and control the spending of various housing funds. Second, in spite of the positive effects of these policy measures, the growth rate of total consumption spending was faster than the growth 
rate of the total consumption spending on household facilities, articles services and residence. To illustrate, during the period between 1985 and 1998, the urban household per capita annual consumer expenditure increased from 991.8 to 6866.41 yuan, representing an annual growth rate of $16 \%$. Whereas, in the same time period, the total consumption spending on household facilities, articles services and residence increased from 201.96 to 1126.43 yuan, representing an annual growth rate of $14 \%$.

Housing reform in Shanghai has raised large amount of non-state capital in housing construction. The HPFs has accumulated over the years 251.99 billion yuan which are used for housing investment. Private housing investment in the forms of real estate corporations also became an important funding source of housing construction. In 1998, there were more than 1,400 real estate corporations in Shanghai. Some have come from other provinces and others were set up by investors from overseas. In 1993, for example, the former accounted for one sixth of the total. Real estate corporations build mainly for commercial purposes and sell houses at market value. Although there were development companies working in every province, Shanghai was in the lead of land, housing and rental markets in China (Han 1998). Nearly half of the real estate development investment was concentrated in Shanghai, Beijing and Guangdong. The other important areas include provinces along the coast. Real estate development in the central and western regions did not take off in the same way (People's Daily, 27 December 1995).

Figure 6 gives the percentage of different investment channels in the total housing investment in Shanghai from 1985 to 1998. On average, the percentage of self-raised capital had been higher than other sources of investment. The self-raised capital 
increased from $46 \%$ in 1985 to nearly $65 \%$ in 1994, then dropped gradually to $54 \%$ in 1998. The capital from the state budget declined from $13 \%$ in 1985 to $3 \%$ in 1998 . Macroeconomic factors have played an important role in Shanghai. Following Deng Xiaoping's inspection of China's coastal areas and subsequent speech on strengthening the reform process and speeding up economic growth in early 1992, the economy grew at an alarming rate. Statistics shows that GDP in Shanghai was 1114.32 billion yuan in 1992 and it rose to 3688.2 billion yuan in 1998, which is more than 3.3 times of 1992. The rapid economic expansion was fuelled mainly by the expansion of investment demand. At the same time real estate and stock market fever created a flow of funds from investments and various other channels, and this led to credit expansion and a currency supply that was out of control. Under such severe situation, the Chinese government took decisive measures late in 1993, and raised the curtain of macroeconomic retrenchment. Influenced by the macroeconomic control from 1993 to 1996, investment in Shanghai's real estate market had been dropping during this period, holding steadily from 1997-98 and began to increase since 1999 according to the latest report from Shanghai real estate market (see Figure 6).

Shanghai's construction industry has been a key sector in its economic development, especially with the construction of Pudong area. The total output value of construction industry raised from 16.41 billion yuan in 1980 to 573.37 billion yuan in 1999. The construction industry has absorbed a large number of labors. Statistics shows that there were 272,700 employees working in the construction industry in 1980, the number increased to 374,00 in 1997. 
The development of housing reform and growth of construction industry has caused sound development of several industrial sectors. Among the twelve selected industrial sectors, the furniture industry and the plate glass industry have achieved the fastest growth rate (Table 5). The output value of furniture industry increased gradually from 2.83 million yuan in 1985 to 9.81 million yuan in 1993. It increased from 14.72 million yuan in 1994 to 29.28 million in 1998 after dropped a little bit in 1996. The total output value in 1998 was more than 10 times that of 1985 . The Statistics of the plate glass industry shows that from 1985 to 1998 output value of plate glass industry increased from 160.08 million tons to 701.45 million tons. Most of the increase was achieved after 1990. There was also a considerable increase in the civil engineering industry. From 1993 to 1998, the output value increased from 91.52 million yuan to 321.87 million yuan.

Table 6 shows the Pearson correlation coefficients for those variables that yield significant relationships with the housing development indicator. Among the twelve variables that represent housing related industries, nine show significant direct relationship with housing investment in Shanghai. These nine variables are: (a) furniture manufacturing; (b) electric equipment and machinery (c) electricity, steam and hot water production and supply; (d) gas production and supply; (e) tap water production and supply; (f) cement; (g) steel (h) plate glass; (i) plastics. The coefficients of the above seven variables are supportive of a statement that there is a close and direct relationship between housing investment and development of related industries, especially building material industry in Shanghai. 


\section{Conclusions}

Housing industry has been regarded as a pillar industry that stimulates national economic growth in China. Yet the impact of housing reform on consumption, investment, and industrial growth through which housing industry contribute to national economy remains unclear. This study contributes to the literature of housing reform and economic growth study by examining such impact, using three cities as example.

Research findings revealed that housing reform resulted in drastic changes in housing investment and growth of related industries. Self-raised capital became the main source of housing investment, while state investment declined considerably. Significant correlations were clearly discernible between housing investment and related industries. Nevertheless, the power of resident's consumption, as measured by the percentage expenditure on real property, household articles and services, was a constraint against housing commercialization.

The Chinese reform approach has been characterized by dramatic policy changes accompanied by minimal alteration of the existing system. Other post-socialist societies have tended to tackle the problems left over from socialism through structural change, such as rapid privatization. In China, reform has brought some significant policy changes, such as increased rents and housing investment, but the structure--the system of ownership and distribution--has changed only slowly. Further more, Housing is one of the last urban sectors to undergo reform. This is not only because of its technical complexities, but also due to the political difficulties involved. 
People's values have developed under the influence of socialist distributive principles and thus public opinion has to be reconciled with a new set of values based on market exchange. Reformers have to deal with popular resistance and dissatisfaction with the new inequalities in an emerging housing market. This might be the main reason for unsatisfactory result of housing commercialization. And the lack of effective demand

It is believed that the following issues deserving more attention in deepening the housing reform and developing the housing industry into an engine of economic growth: First, housing sales should target for domestic buyers instead of foreign consumers. Second, easier access to the mortgage loan should be introduced to all private house buyers. Finally, a market-oriented housing price system should be formed to rationalized rent and housing price.

\section{References}

Chen, S.P. 1993, "Urban Housing Reform in China” Working Paper No.7, Asia Research Center, Murdoch University, Perth

Dipasquale, Denise and Wheaton, William C. 1996, Urban Economics and Real Estate Markets, Chapter 7, pp.155-81, Prentice Hall

Ermisch, John 1990, "The Background: Housing Trends and Issues Arising from Them" Housing and the National Economy, Gower Publishing Company

Gaubatz, I. 1995, “Changing Beijing” The Geographical Review, 85(1) pp.79-96 
Han, S.S. 2000, "Shanghai: between state and market in urban transformation" Urban Studies, Vol. 37, No. 11, 2091-2112.

Han, S.S. 1998, "Real Estate Development in China: A Regional Perspective" Journal of Real Estate Literature 6 (2): pp.121-33

Institution of Finance and Trade Economic (IFTE), Chinese Academy of Social Sciences (CASS) and Institute of Public Administration (IPA) (New York) 1996, China's Urban Housing Reform, Economy and Management Publishing House

Li, S.M. 2000, "Housing Consumption in Urban China: a Comparative Study of Beijing and Guangzhou" Environment and Planning A 32 pp.1115-34

Lim, G.C and Lee, M.H 1993, "Housing Consumption in Urba Journal of Real Estate Finance and Economics, (6) pp.89-10

Office of Leading Group for Housing Reform under State Council 1991, "Try to Build Hundreds and Thousands of Houses" Gaige Publishing House

Mei, Sheng 1999, "Ru He Kan Dai Zhong Guo De Zhu Zhai Chan Ye”, Real Estate Periodical, (2) pp.35-7

Wang, Y.P. 1992, "Private-sector Housing in Urban China Since 1949: the Case of Xian” Housing Studies, 7(2), pp.119-37 
Wang, Y.P. and Murie, A. 1996, "The Process of Commercialisation of Urban Housing in China" Urban Studies 33(6) pp. 971-89

Wang, Y.P. and Murie, A.1999, “Commercial Housing in urban China” Urban Studies 36(9) pp. 1475-94

World Bank 1992, “China: implementation options for urban housing reform-a World Bank country study", World Bank, Washington, DC.

Xie, Y.C. and Costa, F. 1991, "Urban Design Practice in Socialist China” Urban Studies 13(3) pp.277-96

Yan, X.W. and R.W. Marans 1995, "Perception of housing in Beijing" Third World Planning Review, 17(1) pp.19-39

Yuan, Shiming 1998, "Evaluation of Urban Housing Reform” China's Reform and Economic Growth, NCDS Asia Pacific Press pp.424-56 
Table 1. Major Economic Indicators of Sample Cities

\begin{tabular}{|c|c|c|c|c|}
\hline Cities & National & Yantai & Shenzhen & Shanghai \\
\hline GDP per capita (yuan) & 6,392 & 11,439 & 35,896 & $28,227.89$ \\
\hline GDP growth rate (97-98) & $5.6 \%$ & $0.7 \%$ & $14.07 \%$ & $10.3 \%$ \\
\hline Population (10000 persons) & $15,402.08$ & 81.86 & 405.13 & 893.72 \\
\hline $\begin{array}{l}\text { Population Density in urban areas } \\
\text { (capita/sq.km) }\end{array}$ & 689 & 593 & 2079 & 3295 \\
\hline Land area (sq.km) & $2,730,866$ & 13,746 & 1,949 & 6,341 \\
\hline $\begin{array}{l}\text { Per capita net living space in } \\
\text { urban areas (sq.m) }\end{array}$ & 9.3 & 15.47 & 15.3 & 13.91 \\
\hline $\begin{array}{l}\text { Direct Foreign Investment (USD } \\
\text { 10000) }\end{array}$ & $4,614,199$ & 45,800 & 275,422 & 363,786 \\
\hline Primary industry to GDP & $18.4 \%$ & $17.9 \%$ & $1.2 \%$ & $2.1 \%$ \\
\hline Secondary industry to GDP & $48.7 \%$ & $51.2 \%$ & $50.6 \%$ & $50.1 \%$ \\
\hline Tertiary industry to GDP & $32.9 \%$ & $30.9 \%$ & $48.2 \%$ & $47.8 \%$ \\
\hline
\end{tabular}
1999

Source: China Statistical Yearbook and Individual city Statistical Yearbooks in 1998 and 
Table 3. Total Output Value of Related Industrial Sectors of Yantai 1985-199

\begin{tabular}{|c|c|c|c|c|c|c|c|c|c|c|c|c|c|}
\hline Year & HI & FU & $\mathbf{E E}$ & $\mathbf{E S}$ & GP & TW & $\mathbf{C E}$ & LE & BD & $\mathbf{C M}$ & ST & BR & TI \\
\hline 1985 & 107 & 72.3 & 306.3 & 187.1 & 1.1 & 11.0 & & & & 167.46 & 35504 & 316930 & 18467 \\
\hline 1986 & 150 & 89.8 & 401.4 & 225.9 & 1.2 & 13.1 & & & & 208.50 & 44749 & 409800 & 17200 \\
\hline 1987 & 108 & 85.2 & 365.4 & 215.5 & 1.1 & 10.5 & & & & 188.80 & 50306 & 289100 & 15100 \\
\hline 1988 & 122 & 115.4 & 503.1 & 281.2 & 1.2 & 13.7 & & & & 237.01 & 52473 & 270554 & 8066 \\
\hline 1989 & 44 & 120.5 & 634.0 & 312.9 & 1.4 & 12.4 & & & & 247.28 & 55300 & 233700 & 6600 \\
\hline 1990 & 210 & 146.6 & 660.8 & 347.6 & 2.9 & 11.8 & & & & 252.00 & 63300 & 209100 & 5520 \\
\hline 1991 & 312 & 157.7 & 995.3 & 576.4 & 14.7 & 20.8 & & & & 320.32 & 77600 & 226600 & 5900 \\
\hline 1992 & 579 & 194.0 & 1272.8 & 632.3 & 20.1 & 22.0 & & & & 437.87 & 80100 & 296900 & 6100 \\
\hline 1993 & 1243 & 353.2 & 2092.1 & 835.5 & 53.8 & 24.7 & & & & 570.00 & 107300 & 360500 & 7388 \\
\hline 1994 & 1258 & 293.6 & 2753.4 & 816.9 & 24.5 & 34.2 & 1031.2 & 83.9 & 61.8 & 692.00 & 95300 & 366100 & 6524 \\
\hline 1995 & 355 & 287.3 & 3969.3 & 958.5 & 28.4 & 29.3 & 1257.1 & 131.3 & 61.1 & & & & \\
\hline 1996 & 350 & 402.1 & 4527.8 & 1058 & 31.3 & 34.2 & 3159.6 & 236.1 & 141.8 & 836.29 & 33200 & 00 & 10904 \\
\hline 1997 & 430 & 400.2 & 5078.3 & 1105.6 & 30.9 & 33.8 & 3200.4 & 271.9 & 185.0 & 833.77 & 65900 & 341400 & 10917 \\
\hline 1998 & & 251.4 & 5889.3 & 1003.3 & 28.7 & 29.6 & 3110.3 & 326.7 & 89.3 & 623.64 & & & \\
\hline
\end{tabular}

Table 4. Total Output Value of Related Industrial Sectors of Shenzhen 1990-1998

\begin{tabular}{|c|c|c|c|c|c|c|c|c|c|c|c|c|c|}
\hline Year & HI & FU & EE & $\mathbf{E S}$ & GP & TW & $\mathbf{C E}$ & $\mathbf{L E}$ & BD & CM & ST & PG & PL \\
\hline 1990 & 1645 & 141.6 & 885.1 & 184.5 & & 50.1 & & & & 22.28 & 56481 & 207 & 103779 \\
\hline 1991 & 3155 & 176.2 & 1206.2 & 187.9 & & 53.5 & & & & 28.17 & 65073 & 238 & 233094 \\
\hline 1992 & 7039 & 205.6 & 1555.1 & 308.9 & & 63.0 & & & & 29.53 & 61300 & 269 & 244000 \\
\hline 1993 & 5823 & 312.1 & 2173.6 & 382.9 & & 90.0 & & & & 31.4 & 60599 & 265 & 290508 \\
\hline 1994 & 6168 & 253.8 & 2607.8 & 1582.9 & & 112.7 & & & & 37.53 & 86538 & 259 & 375757 \\
\hline 1995 & 7959 & 219.4 & 3822.8 & 1454.7 & 63.82 & 188.1 & & & & 30.09 & 93090 & 272 & 449183 \\
\hline 1996 & 8598 & 262.1 & 4856.9 & 1577.4 & 6.40 & 227.7 & & & & 25.17 & 100000 & 272 & 411132 \\
\hline 1997 & 11351 & 276.1 & 5943.4 & 11298.2 & 1.17 & 757.4 & & & & 17.48 & 73501 & 385 & 387692 \\
\hline 1998 & 15005 & 857.8 & 9228.5 & 11871.0 & 160.03 & 795.1 & & & & 16.17 & 81635 & 238 & 256327 \\
\hline
\end{tabular}

Table 5. Total Output Value of Related Industrial Sectors of Shanghai 1985-1998

\begin{tabular}{|c|c|c|c|c|c|c|c|c|c|c|c|c|c|}
\hline Year & HI & FU & $\mathbf{E E}$ & $\mathbf{E S}$ & GP & TW & $\mathbf{C E}$ & LE & BD & $\mathbf{C M}$ & ST & PG & PL \\
\hline 1985 & & 2.83 & 48.53 & 13.27 & 3.58 & 1.38 & & & & 219.31 & 570.16 & 160.08 & 17.46 \\
\hline 1986 & & 2.89 & 52.92 & 13.83 & 3.60 & 1.40 & & & & 227.28 & 801.39 & 146.44 & 17.77 \\
\hline 1987 & & 3.26 & 56.43 & 13.68 & 3.73 & 1.50 & & & & 232.81 & 866.92 & 161.85 & 17.76 \\
\hline 1988 & 1428 & 3.58 & 63.44 & 14.27 & 3.51 & 1.64 & & & & 261.84 & 859.80 & 415.59 & 18.07 \\
\hline 1989 & 1255 & 3.60 & 67.38 & 14.26 & 3.51 & 1.67 & & & & 251.85 & 808.78 & 507.24 & 17.96 \\
\hline 1990 & 2566 & 4.84 & 101.50 & 23.22 & 3.83 & 3.83 & & & & 230.30 & 914.62 & 503.05 & 25.35 \\
\hline 1991 & 2799 & 5.36 & 117.95 & 25.51 & 7.44 & 4.02 & & & & 297.85 & 1006.92 & 483.47 & 33.91 \\
\hline 1992 & 2668 & 6.74 & 155.60 & 50.49 & 6.83 & 4.81 & & & & 354.73 & 1234.24 & 513.55 & 42.32 \\
\hline 1993 & 7714 & 9.81 & 220.68 & 74.46 & 8.77 & 7.19 & 91.52 & 10.36 & 4.98 & 359.88 & 1298.22 & 570.72 & 51.46 \\
\hline 1994 & 30065 & 14.72 & 292.05 & 98.72 & 12.42 & 9.69 & 160.46 & 15.63 & 8.87 & 379.44 & 1326.77 & 664.81 & 56.22 \\
\hline 1995 & 40782 & 17.73 & 323.63 & 92.73 & 13.55 & 11.36 & 165.67 & 18.10 & 11.61 & 433.22 & 1454.11 & 634.63 & 58.24 \\
\hline 1996 & 43385 & 12.72 & 304.17 & 107.51 & 15.25 & 12.51 & 209.10 & 30.25 & 23.61 & 443.77 & 1441.92 & 687.63 & 65.46 \\
\hline 1997 & 43305 & 29.73 & 406.46 & 145.99 & 17.89 & 14.56 & 306.10 & 40.46 & 37.72 & 338.47 & 1532.42 & 691.08 & 64.56 \\
\hline 1998 & 38327 & 29.28 & & & & & 321.87 & 35.32 & 41.88 & 330.95 & 1603.75 & 701.45 & \\
\hline
\end{tabular}

Notes:

1. Abbreviations in table 2-4: HI-Housing Investment; FU-Furniture; EE-Electric

Equipment and Machinery; ES-Electricity, Steam and Hot Water Production and

Supply; GP-Gas Production and Supply; TW-Tap Water Production and Supply; CE-

Civil Engineering; LE-Line Equipment Installation; BD-Building and Decoration;

CM-Cement (million tons); ST-Steel (million tons); BR-Brick (million pieces); TI-

Tile (million pieces); PG-Plate Glass (million cases); PrPlastics (million tons) 
2. Unless sated, all the output values are measured in million yuan and are calculated based on the constant price in 1990

Table 6 Correlation coefficients of related industries which show a close relationship with housing investment

\begin{tabular}{llll}
\hline Industries & Yantai & Shenzhen & Shanghai \\
\hline Civil Engineering & -0.608 & N/A & 0.710 \\
Line and Equipment Installation & -0.695 & N/A & 0.741 \\
Building Decoration & -0.497 & N/A & 0.631 \\
$\begin{array}{l}\text { Electricity, Steam and Hot } \\
\text { Water Production and Supply }\end{array}$ & $0.564^{*}$ & $0.857^{* *}$ & $0.91^{* *}$ \\
Gas Production and Supply & $0.775^{* *}$ & 0.697 & $0.948^{* *}$ \\
$\begin{array}{l}\text { Tap Water Production and } \\
\text { Supply }\end{array}$ & $0.625^{*}$ & $0.886^{* *}$ & $0.956^{* *}$ \\
$\begin{array}{l}\text { Electric Equipment and } \\
\text { Machinery }\end{array}$ & 0.372 & $0.953^{* *}$ & $0.934^{* *}$ \\
Furniture Manufacturing & $0.612^{*}$ & $0.8^{* *}$ & $0.849^{* *}$ \\
Cement & $0.597^{*}$ & -0.536 & $0.725^{*}$ \\
Steel & $0.845^{* *}$ & 0.487 & $0.873^{* *}$ \\
Plate Glass & N/A & 0.463 & $0.931^{* *}$ \\
Plastics & N/A & 0.448 & $0.872^{* *}$ \\
\hline
\end{tabular}

Notes: ** Correlation is significant at 0.01 level (2-tailed);

* Correlation is significant at 0.05 level (2-tailed). 


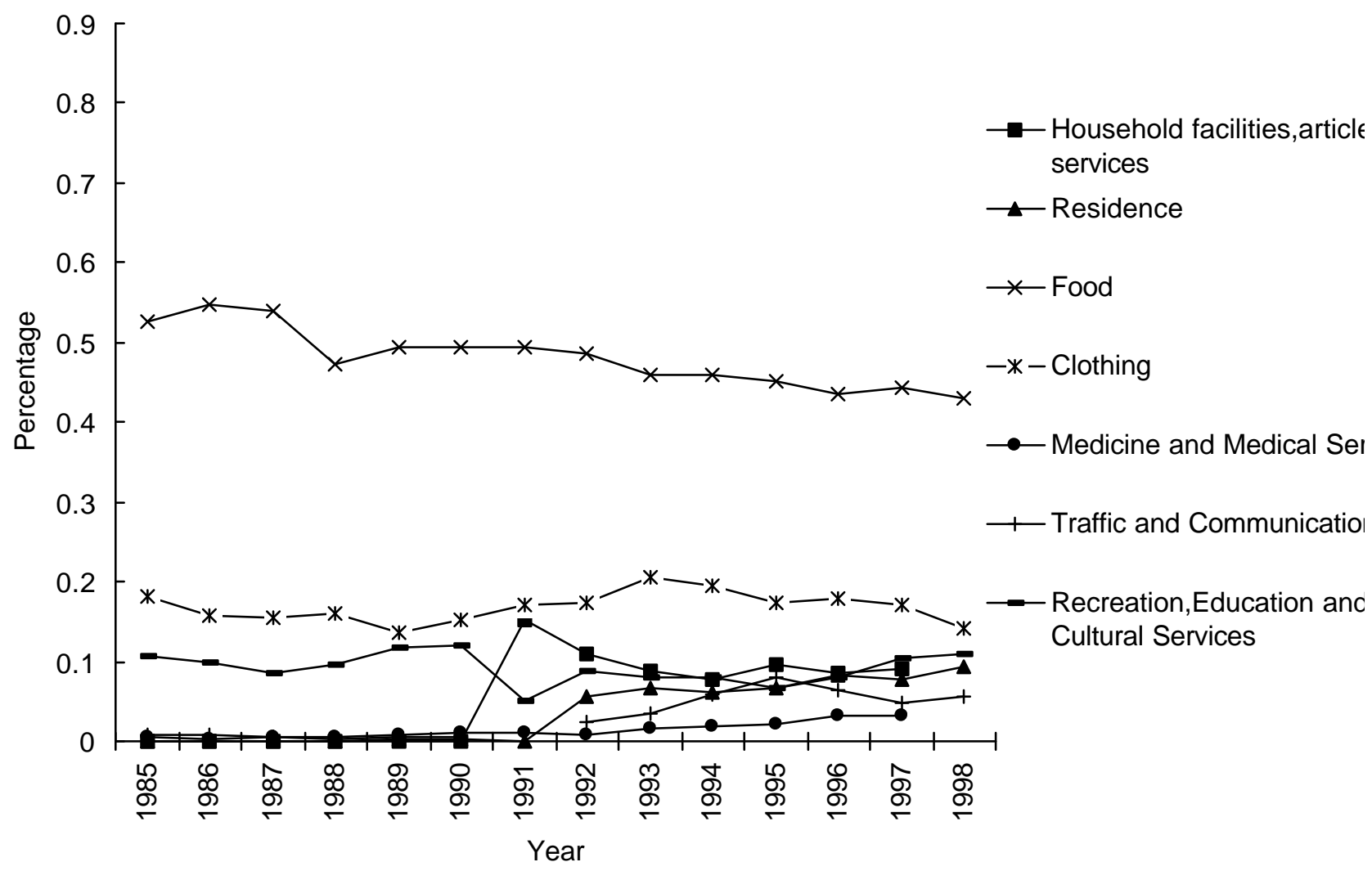

Figure 1. Households Consumption in Yantai 1985-1998 


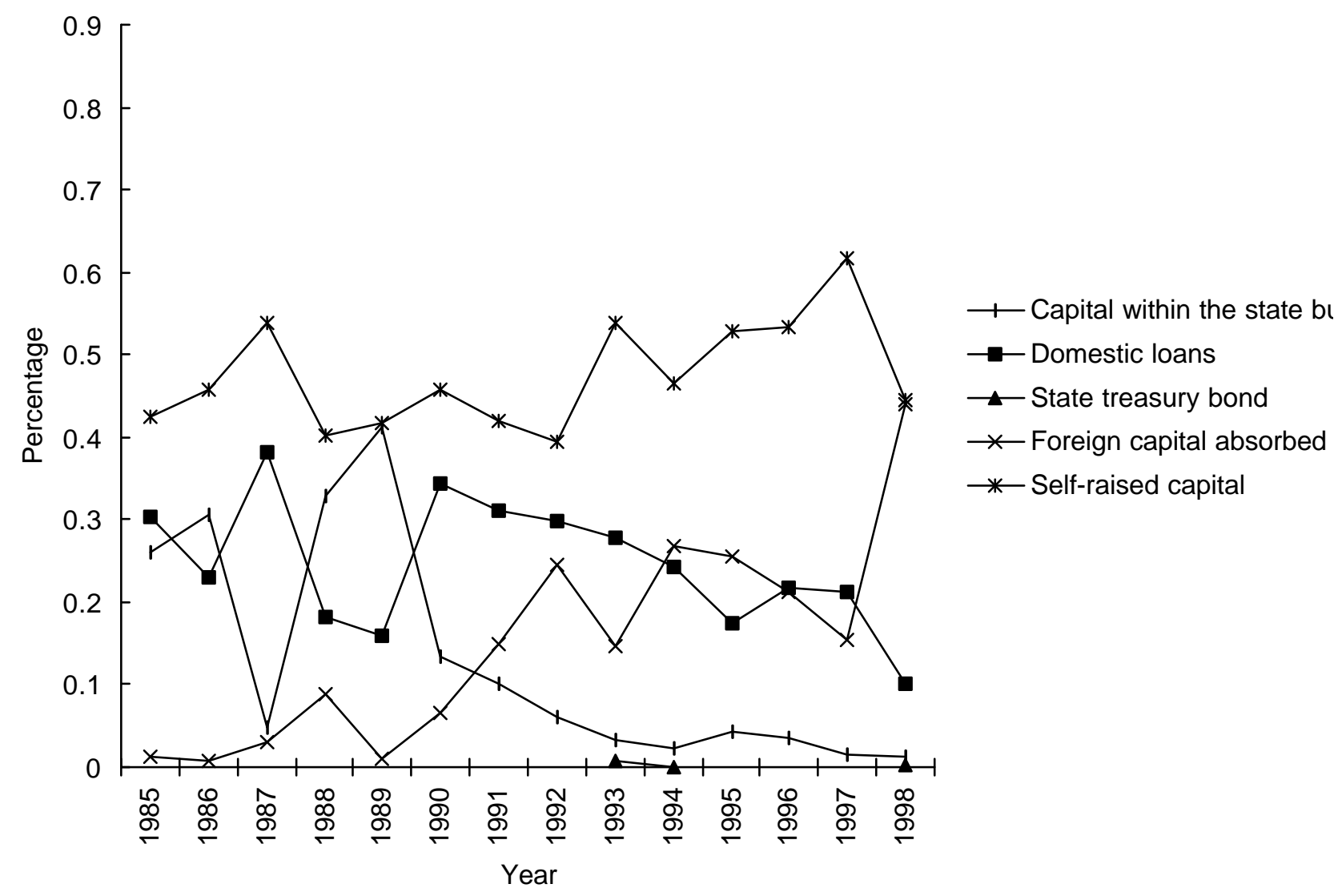

Figure 2. Housing Investment in

Yantai 


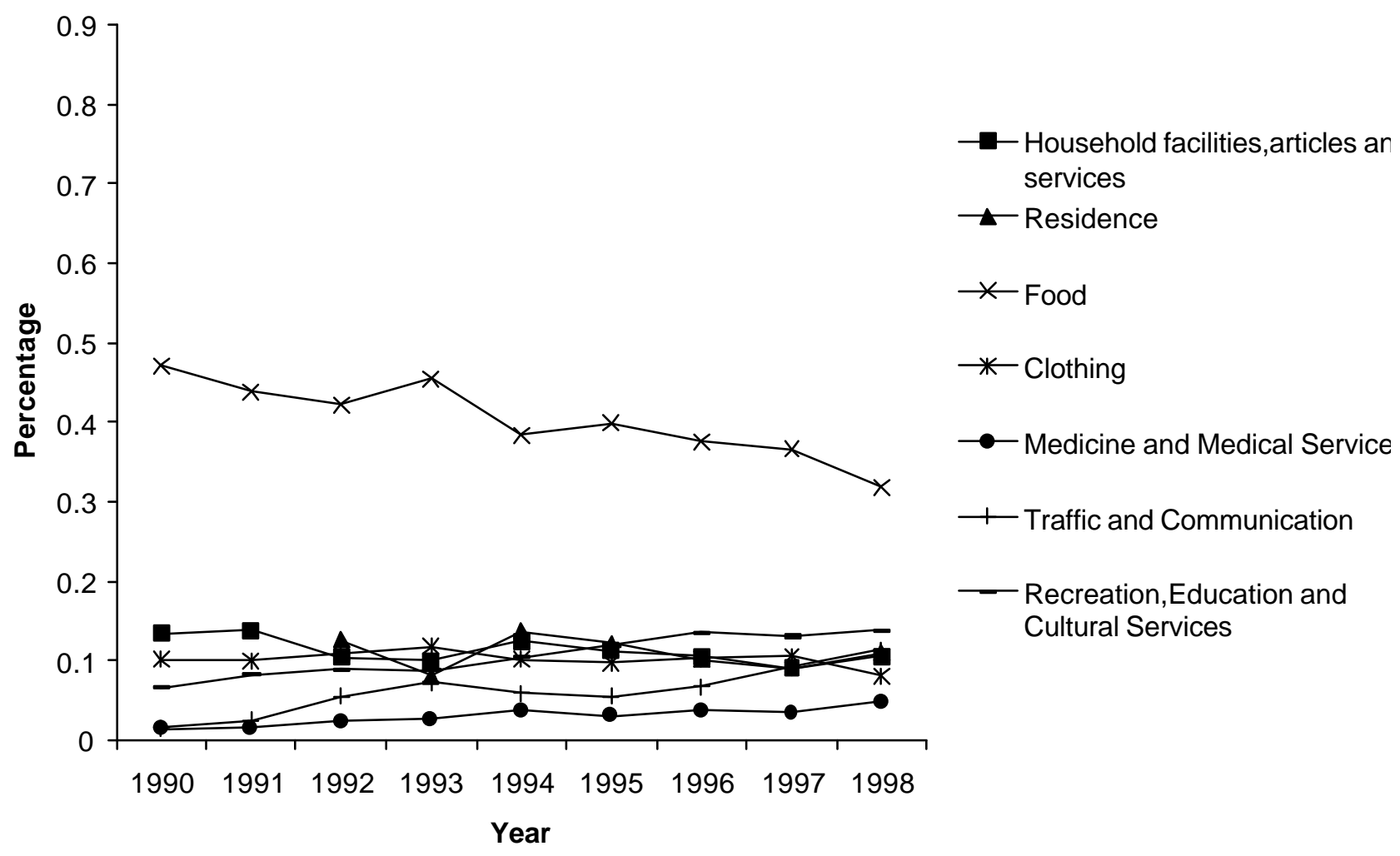

Figure 3. Households Consumption in Shenzhen 1990-

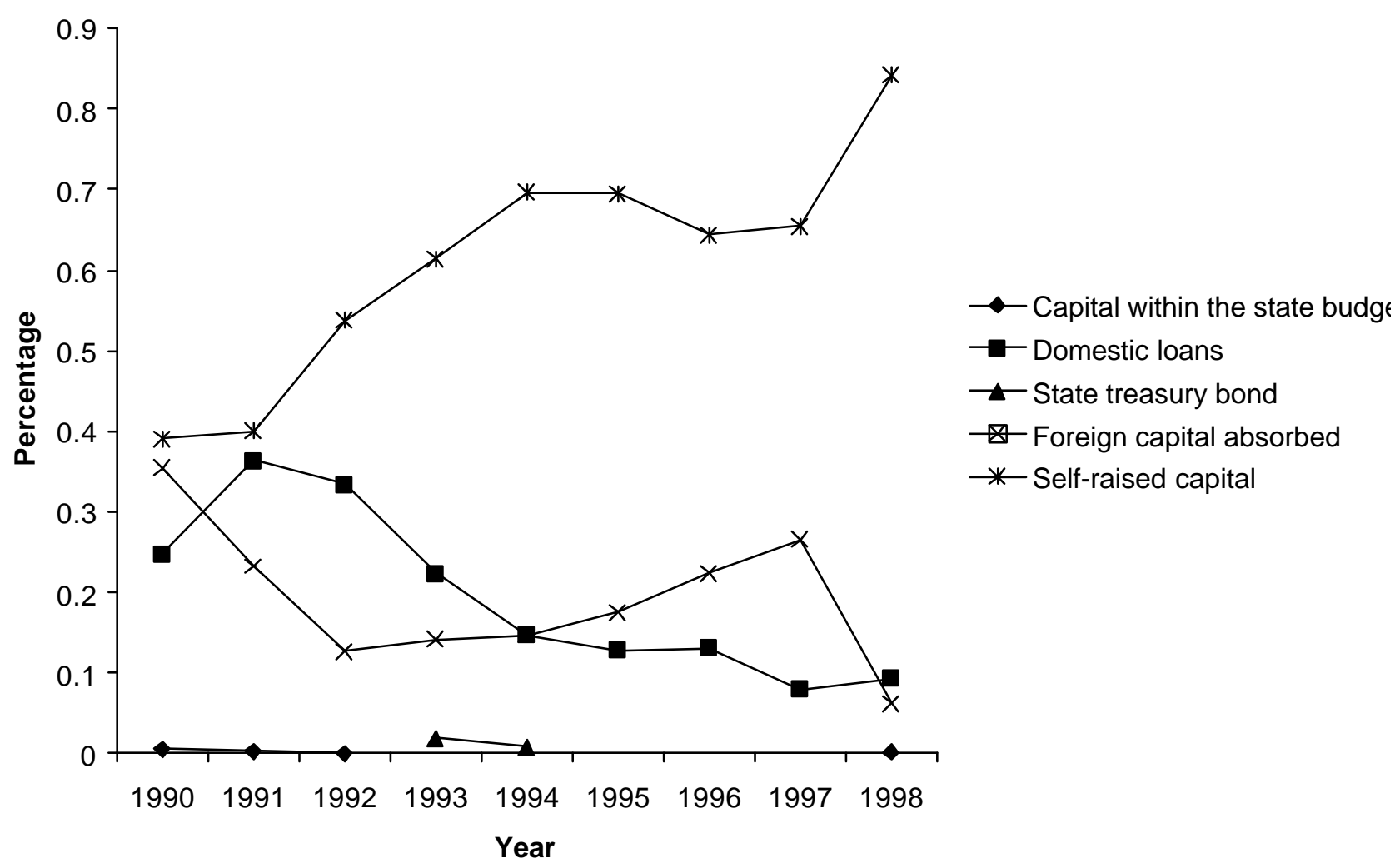

Figure 4. Housing Investment in Shenzhen 1990-1998 


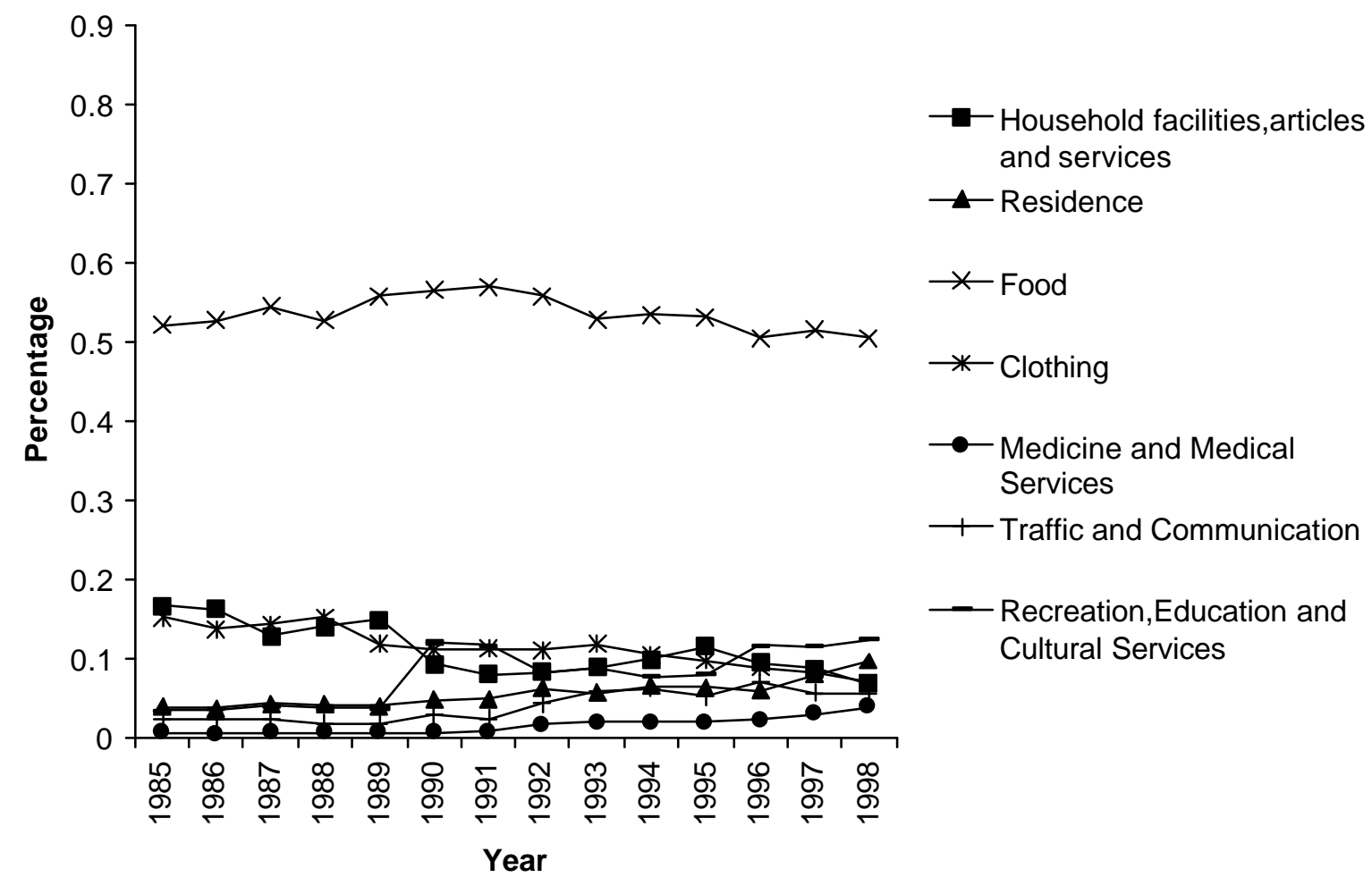

Figure 5. Households Consumption in

Shanghai 1985-1998 


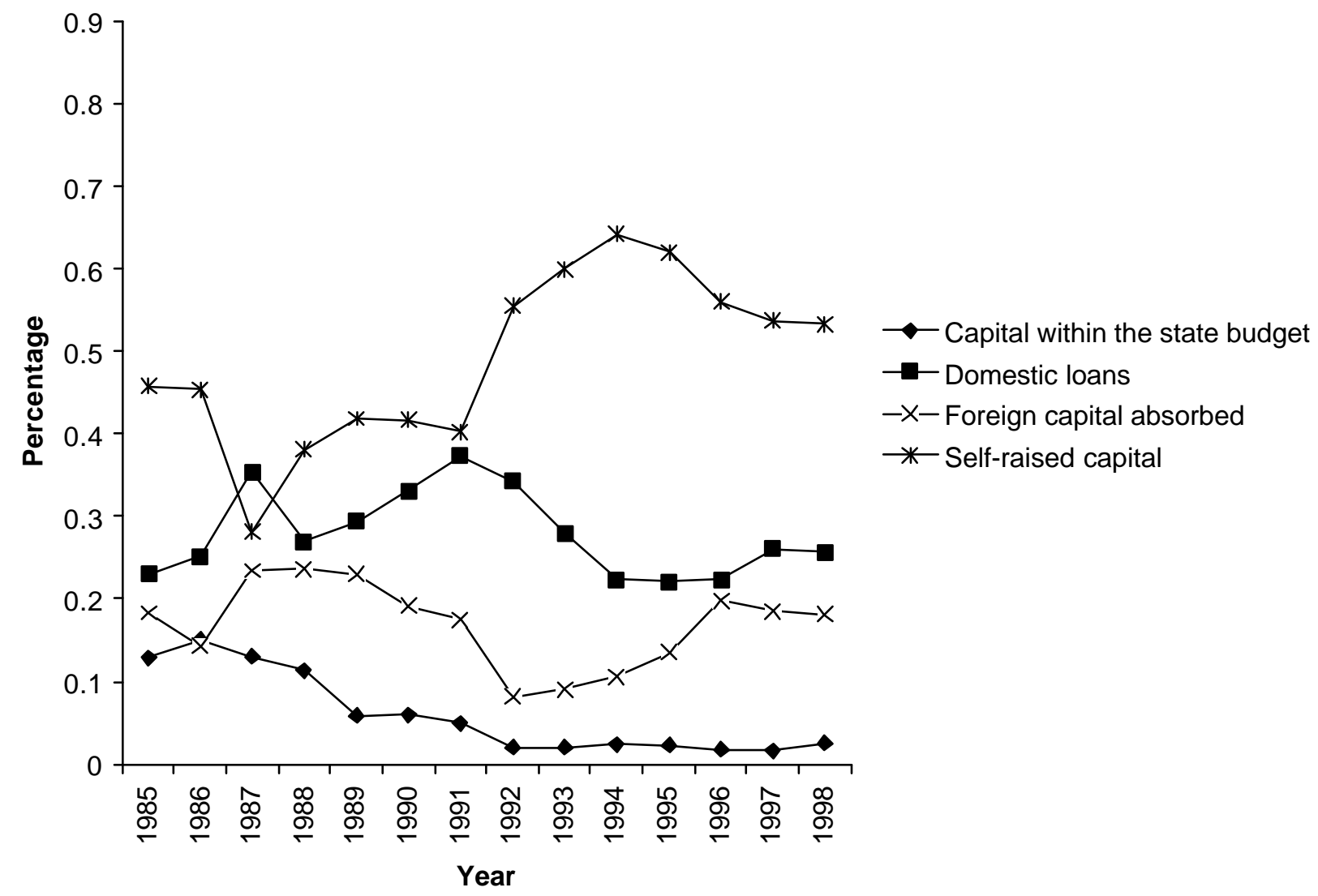

Figure 6. Housing Investment in

Shanghai 
Table 2 Main Reform Events in Sample Cities

\begin{tabular}{|c|c|c|c|}
\hline National & Yantai & Shenzhen & Shanghai \\
\hline \multicolumn{4}{|l|}{$\begin{array}{l}\text { The First Housing Reform Experiment in } \\
\text { 1979: } \\
\text { Build housing for sale at the basic } \\
\text { building costs }\end{array}$} \\
\hline Commercialization for urban housing & $\begin{array}{l}\text { The establishment of } \\
\text { housing bank in } 1985\end{array}$ & & \\
\hline $\begin{array}{l}\text { 1.To adjust rents in the public sector } \\
\text { 2. To introduce housing subsidy and to } \\
\text { promote sales of public-sector housing }\end{array}$ & $\begin{array}{l}\text { Selected for the second } \\
\text { Housing Reform } \\
\text { Experiment }\end{array}$ & $\begin{array}{l}\text { 1. Housing Reform Plan of Shenzhen } \\
\text { Special Economic Zone was } \\
\text { promulgated in } 1988 \\
\text { 2. Land management reform in } \\
\text { 1988 }\end{array}$ & \\
\hline $\begin{array}{l}\text { 1. The First National Housing Reform } \\
\text { Conference in } 1988 \\
\text { 1.Establish provident fund } \\
\text { 2. Increasing rent and issuing housing } \\
\text { coupons } \\
\text { 3. The requirement of new public-sector } \\
\text { tenant to pay a large deposit } \\
\text { 4. Provide discounts for housing purchase } \\
\text { 5. Establish local housing committees }\end{array}$ & & $\begin{array}{l}\text { 1. Outline of housing development in } \\
\text { Shenzhen Special Economic Zone } \\
\text { was promulgated in July } 1989 \\
\text { 2. Publish of Housing Reform theory } \\
\text { and Practice of Shenzhen Special } \\
\text { Economic Zone in } 1991 \\
\text { 3. Set up of Housing Exchange } \\
\text { Institute in August } 1989 \\
\text { 4. Set up Housing Leasing Office in } \\
\text { charge of private housing rent in } \\
\text { 1991 }\end{array}$ & \\
\hline $\begin{array}{l}\text { 1. Urban Housing Reform resolution } 1991 \\
\text { 2. Anju Settlement Plan for } 1994 \text { to } 1996\end{array}$ & & $\begin{array}{l}\text { Sale of housing based on the building } \\
\text { area in } 1992\end{array}$ & The establishment of $\mathrm{HI}$ \\
\hline $\begin{array}{l}\text { The publish of "The Decision on Deepening } \\
\text { the Urban Housing Reform" in 1994: }\end{array}$ & & $\begin{array}{l}\text { 1. Promulgated } 11 \text { design principles } \\
\text { on Anju housing in } 1997 \text { which } \\
\text { emphasize design, technology and } \\
\text { quality } \\
\text { 2. Reinforce the property } \\
\text { management, emphasize the concept } \\
\text { of management in stead of simple } \\
\text { construction }\end{array}$ & $\begin{array}{l}\text { 1.Promulgation of "Ord } \\
\text { Housing Provident Fur } \\
\text { Shanghai" in } 1996 \\
\text { 2. To vitalize the seconı } \\
\text { tier real estate market } \\
\text { 3.The publish of "Meas } \\
\text { resale of public housin } \\
\text { by Shanghai's employer }\end{array}$ \\
\hline $\begin{array}{l}\text { Formal end of state-subsidized housing by } \\
\text { January } 1^{\text {st }}, 2000\end{array}$ & & Rent raised to 6.54 yuan/sq m/month & \\
\hline
\end{tabular}

